О. П. Евсеева, П. В. Шумская

Белорусский государственный технологический университет

\title{
РЕКОМЕНДАЦИИ ПО ЛАНДШАФТНОЙ АДАПТАЦИИ АРХИТЕКТУРНО-ПРОСТРАНСТВЕННОЙ СРЕДЫ УЧРЕЖДЕНИЙ ОБЩЕГО СРЕДНЕГО ОБРАЗОВАНИЯ ДЛЯ ДЕТЕЙ С ОПФР И ИНВАЛИДОВ
}

В статье приведены статистические данные по республики Беларусь о количестве детей инвалидов и детей с особенностями психофизического развития. Дано обоснование необходимости создания комфортных архитектурно-ландшафтных условий, способствующих пребыванию в учреждении среднего образования. Описаны компоненты архитектурно-ландшафтной среды (внутренней и внешней). Проанализированы данные научно-исследовательских работ, государственные программы, планы мероприятий по проблеме формирования архитектурно-пространственной среды для лиц с ограниченными возможностями.

Приведен анализ состояния проблемы на примере г. Дзержинска Минской области. На основе обследования внешней архитектурно-ландшафтной среды ГУО «Средняя школа № 4 г. Дзержинска» даны результаты соответствия компонентов архитектурно-пространственной среды нормативным показателям, рекомендации по ландшафтной адаптации архитектурно-пространственной среды для детей с особенностями психофизического развития и детей-инвалидов.

Ключевые слова: адаптация, ландшафт, архитектурно-ландшафтная среда, инвалиды, дорожно-тропиночная сеть, нормативные показатели.

Для цитирования: Евсеева О. П., Шумская П. В. Рекомендации по ландшафтной адаптации архитектурно-пространственной среды учреждений общего среднего образования для детей с ОПФР и инвалидов // Труды БГТУ. Сер. 1, Лесное хоз-во, природопользование и перераб. возобновляемых ресурсов. 2021. № 2 (246). С. 121-127.

\author{
O. P. Evseeva, P. V. Shumskaya \\ Belarusian State Technological University \\ RECOMMENDATIONS FOR LANDSCAPE ADAPTATION \\ OF THE ARCHITECTURAL AND SPATIAL ENVIRONMENT \\ OF GENERAL SECONDARY EDUCATION INSTITUTIONS \\ FOR CHILDREN WITH OPFR AND THE DISABLED
}

The article presents statistical data for the Republic of Belarus on the number of children with disabilities and children with special psychophysical development. The article provides a justification for the need to create comfortable architectural and landscape conditions that contribute to staying in a secondary education institution. The components of the architectural and landscape environment (internal and external) are described. The article analyzes the data of research works, state programs, and action plans on the problem of creating an architectural and spatial environment for people with disabilities.

The analysis of the state of the problem is given on the example of Dzerzhinsk, Minsk region. Based on the survey of the external architectural and landscape environment of the State Educational Institution "Secondary School No. 4 of Dzerzhinsk", the results of the compliance of the components of the architectural and spatial environment with the normative indicators are presented. Recommendations on landscape adaptation of the architectural and spatial environment for children with special needs of mental and physical development and children with disabilities are given.

Key words: adaptation, landscape, architectural and landscape environment, disabled people, road and path network, regulatory indicators.

For citation: Evseeva O. P., Shumskaya P. V. Recommendations for landscape adaptation of the architectural and spatial environment of general secondary education institutions for children with OPFR and the disabled. Proceedings of BSTU, issue 1, Forestry. Nature Management. Processing of Renewable Resources, 2021, no. 2 (246), pp. 121-127 (In Russian).

Введение. Ландшафтная адаптация архитектурно-ландшафтной среды учреждений образования для инвалидов и лиц с ОПФР приобретает все большую актуальность в связи с распространением практики смешанного обучения в об- щеобразовательных школах. В настоящее время, по данным от 1 июля 2020 г., в Беларуси на учете в органах по труду и соцзащите состояли 575,7 тыс. человек по инвалидности. По данным от 17 декабря 2020 г., в Беларуси проживают 
170468 детей с особенностями психофизического развития (ОПФР) (рис. 1, 2, 3). Большая часть особенных детей $(60 \%)$ имеют легкие нарушения в развитии, а инвалидность - 14234 человека [1]. Уровень врожденных аномалий у детей до 18 лет составляет $25,3 \%$, у $16,8 \%$ детей причиной инвалидности являются болезни нервной системы, болезни психического расстройства составляют $16,6 \%$. В Республике Беларусь большое внимание уделяется созданию условий для жизни и развития детей с ОПФР и инвалидов. По всей республике функционируют как специализированные, так и смешанного типа учреждения общего среднего образования.

37500

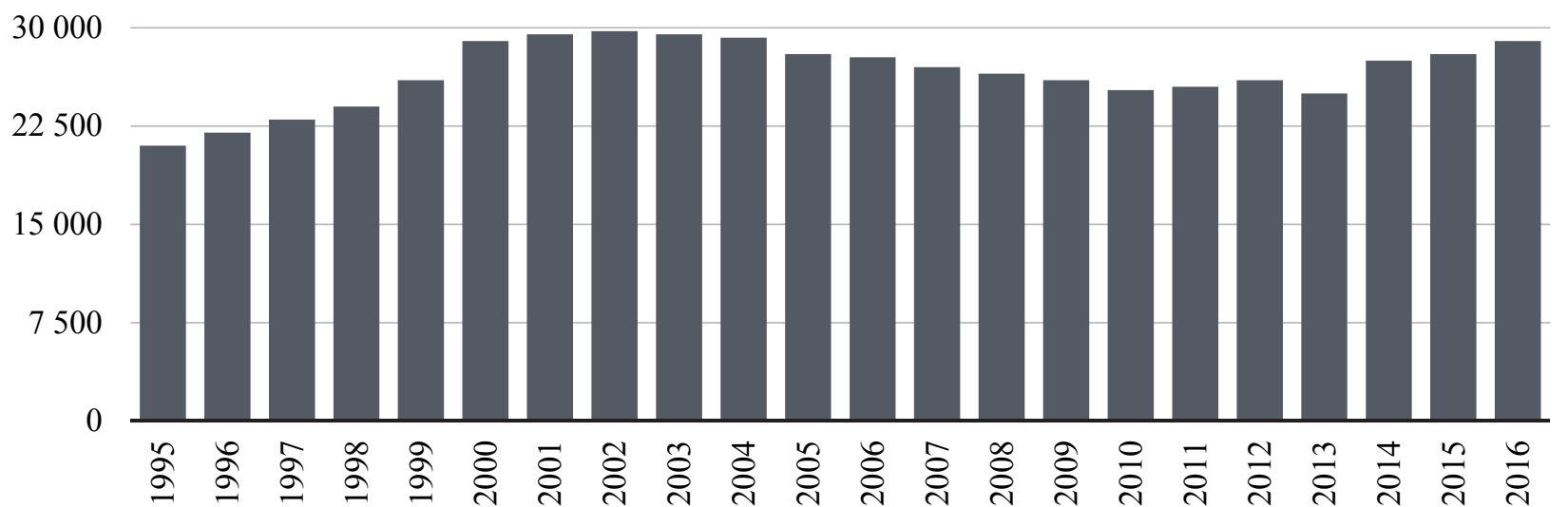

Рис. 1. Численность детей-инвалидов в возрасте до 18 лет, состоящих на учете в органах по труду, занятости и социальной защите (1995-2016 гг.)

187500

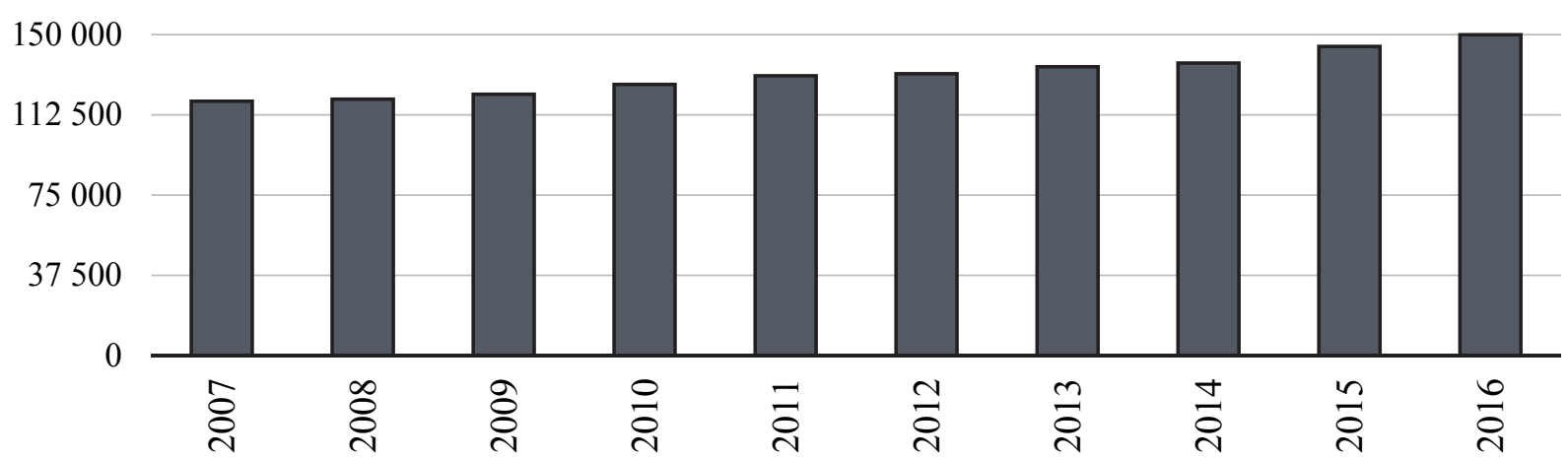

Рис. 2. Количество детей с ОПФР в Республике Беларусь (2007-2016 гг.)

750000

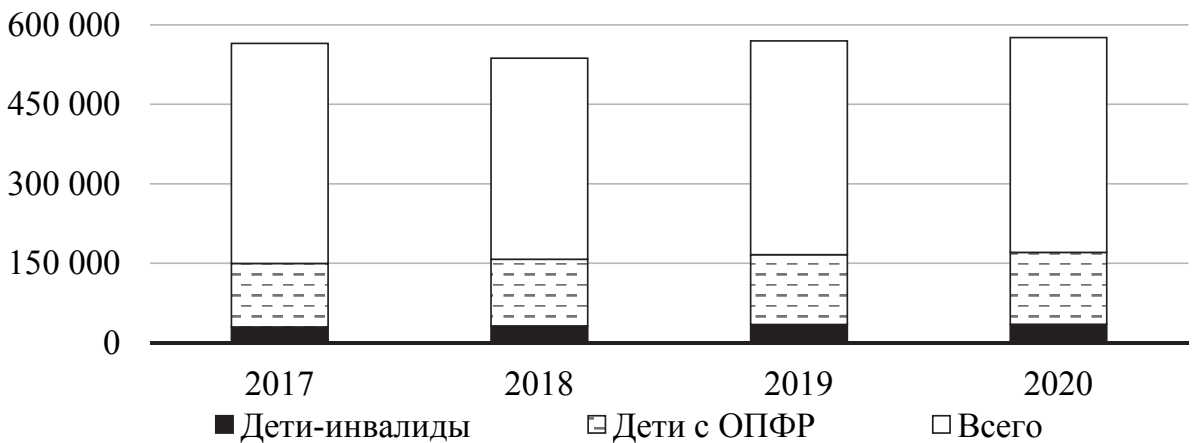

Рис. 3. Статистические данные по количеству детей инвалидов и детей с ОПФР (2017-2020 гг.) 
Получение образования является приоритетом, в том числе в рамках реализации концепции развития инклюзивного образования для лиц с ОПФР на 2015-2020 и последующие годы, т. е. для лиц, имеющих физические и (или) психические нарушения, которые ограничивают его социальную деятельность и препятствуют получению образования без создания для этого специальных условий [2], а также инвалидов, согласно Национальному плану действий по реализации в Республике Беларусь положений Конвенции о правах инвалидов на 2017-2025 годы, - это лицо с устойчивыми физическими, психическими, интеллектуальными или сенсорными нарушениями, которые при взаимодействии с различными барьерами мешают полному и эффективному участию его в жизни общества наравне с другими гражданами [3].

Для данных категорий населения необходимо создание особых архитектурно-пространственных условий для комфортного пребывания и обучения. Под архитектурно-пространственной средой (АПС) подразумеваем ту часть нашего окружения, которая образована архитектурно (художественно) обоснованными объемнопространственными структурами, системами оборудования и благоустройства, объединенными в целостность по законам художественного единства [4]. АПС может быть как внешней (экстерьер), так и внутренней (интерьер). К компонентам внешней АПС относятся дорожки, площадки различного функционального назначения, входы и выходы на территорию, в здания и сооружения, парковки. К компонентам внутренней АПС относят помещения различного функционального назначения, инженерные сооружения для перемещения в горизонтальном и вертикальном пространствах.

Основная часть. В Беларуси с 1990 г. ведутся научно-исследовательские работы, направленные на формирование АПС, доступной для лиц с ограниченными возможностями $[5,6]$. На основании проведенных исследований сформирован комплекс нормативов, позволяющих при архитектурно-планировочной организации жилых территорий и отдельных жилых, общественных, административных зданий и сооружений обеспечивать базовые требования к безбарьерной среде. Нормы о доступности физической среды жизнедеятельности инвалидов находят свое отражение в законодательстве и реализуются с 2007 г. в рамках государственных программ (подпрограмм) по созданию безбарьерной среды жизнедеятельности инвалидов и физически ослабленных лиц. При выполнении мероприятий данных государственных программ (подпрограмм) постоянно увеличивается количество зданий и сооружений, оборудованных элементами безбарьерной среды. Ведется работа по увеличению количества адаптированных для инвалидов социальных, бытовых и других услуг, а также информации.

Помимо инвалидов, передвигающихся на креслах-колясках (примерно 0,1-0,2\% населения), необходимо учитывать особенности ландшафтной адаптации архитектурно-пространственной среды учреждений образования для других групп инвалидов и детей с ОПФР:

- лиц с другими нарушениями опорно-двигательного аппарата (вследствие ампутации, травмы, детского церебрального паралича, артрита, артроза и т. п.). Их специфические требования также, как и предыдущей категории, касаются прежде всего горизонтальных и вертикальных коммуникаций, но они не совпадают с требованиями колясочников;

- слепых и слабовидящих. Этой категории необходимо обогащение информационного поля среды с тем, чтобы компенсировать отсутствие или резкую недостаточность зрительных ощущений, закрепление в пространстве рабочего поля, определенный порядок размещения средовых элементов в границах этого поля и др.;

- глухих и слабослышащих. В этой группе велика доля молодых, активных, спортивных, для которых, как ни для одной другой категории, важна близость к жилищу открытых и закрытых спортивных сооружений;

- с детьми-инвалидами и ОПФР. Их специфические требования, непосредственно связанные с состоянием ребенка, касаются всех уровней среды - от планировки и оборудования учебного пространства и школьного двора до наличия специальных лечебного и учебного оборудования. Учет этих требований чрезвычайно важен, от него зависит степень реабилитации и социализации ребенка.

В целом, по данным отдела образования, в Дзержинском районе проживает 694 детей-инвалидов и детей с ОПФР, что составляет $0,41 \%$ от общего количества детей-инвалидов в Республике Беларусь. Среди учеников анализируемой школы были выделены следующие категории учеников с нарушениями: зрения, слуха, речи, опорно-двигательного аппарата, дети с интеллектуальной недостаточностью и другие заболевания, не входящие в данные категории.

Для анализа состояния внешней АПС был выбран объект ГУО «Средняя школа № 4 г. Дзержинска» (рис. 4), так как данный объект является центром социального обслуживания для детей с ОПФР. Их численность составляет 111 учеников (32 из которых инвалиды), это $11 \%$ от общей численности учеников в школе (рис. 4). 


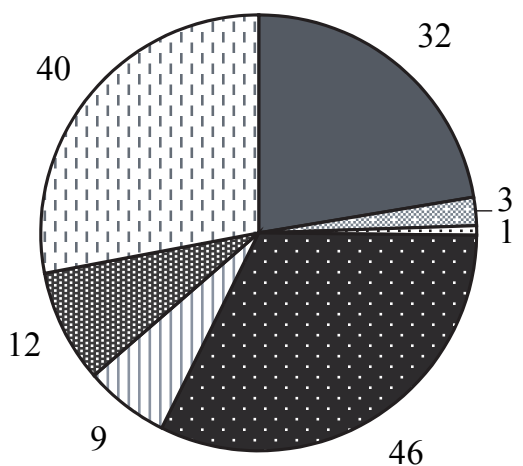

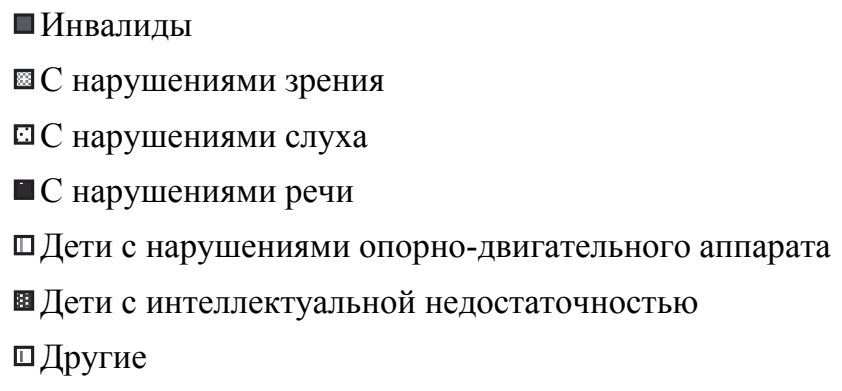

Рис. 4. Численность и категории детей-инвалидов и детей с ОПФР в ГУО «Средняя школа № 4 г. Дзержинска» на момент начала 2021 г.

На основе действующих в Республике Беларусь таких нормативных документов, как СТБ 2030-2010 «Среда обитания для физически ослабленных лиц. Основные положения», СНиП 35-01-2001 «Доступность зданий и сооружений для маломобильных групп населения», Закон Республики Беларусь об архитектурной, градостроительной и строительной деятельности в Республике Беларусь и других нормативно-правовых документов был проведен анализ внешней АПС ГУО «Средняя школа № 4 г. Дзержинска», а именно основных показателей размеров и типов покрытий, необходимых для данной группы населения [7-15]. Более глубокое натурное обследование выявило неприспособленность отдельных зон школьного участка к требованиям лиц с ограниченными возможностями здоровья из-за ряда недостатков: отсутствие пандусов, ограждений, отсутствие площадок для парковки транспортных средств инвалидов, мест отдыха и ожидания, несоответствие типов покрытия, выровненности и ширины дорожного полотна (таблица). АПС проводится с целью создания полноценной функционально-технической организации среды с учетом антропометрических особенностей категории лиц с ОПФР и инвалидов структуре «человек - деятельность - жизненный процесс - пространство».

Требования инвалидов к путям передвижения в рамках ландмафтной адаптации архитектурно-пространственной среды. Основные требования исходят от лиц с нарушениями опорно-двигательного аппарата, которым необходима безбарьерная среда, обеспечивающая им возможность самостоятельного передвижения внутри зданий и на открытом воздухе. Для инвалидов, передвигающихся на кресле-коляске, нужны достаточные размеры путей передвижения и проемов на их пути, наличие мест для разворота коляски, отсутствие порогов и других резких перепадов высот, устройство пандусов, подъемников и лифтов там, где такие перепады неизбежны. Для лиц с другими поражениями опорно-двигательного аппарата важен уклон лестниц, наличие ограждений определенной высоты с удобными для охвата кистью перилами. Для всех важно размещение, нескользкие покрытия путей передвижения, в том числе при охлаждении и увлажнении. Для слабовидящих требуется контрастное выделение краев ступеней, для слепых - ограничительные бортики на дорожках и лестницах.

В результате обследования территории УО «Средняя школа № 4 г. Дзержинска» выявлено, что к основным зданиям и системам дорожно-тропиночной сети доступ обеспечен, тип покрытия и их ширина отвечают необходимым нормам, перечисленные компоненты являются основополагающими и занимают большую часть территории. Компоненты АПС на территории хозяйственной части школы и в зоне спортивной площадки нуждаются в адаптации для детей с ОПРФ и инвалидов, дорожно-тропиночная сеть не соответствуют нормативным требованиям. Для этого необходимо провести ремонтные работы по замене покрытия и увеличению ширины дорожек, выполнить адаптацию существующих лестничных спусков, которые не соответствуют требованиям и отличны от норм. Входы и выходы на территорию и в здания и сооружения соответствуют предъявляемым требованиям.

Заключение. Проблема адаптации архитектурно-пространственной среды остается актуальной для Республики Беларусь несмотря на то, что действия по ландшафтному улучшению архитектурного пространства уже начали реализовываться и набирают скорость в своем осуществлении на государственном уровне. Ежегодно увеличивается численность детей-инвалидов и детей с ОПФР, возрастает потребность в адаптации учреждений образования к данным категориям населения. 
Анализ соответствия компонентов архитектурно-пространственной среды требованиям нормативных показателей

\begin{tabular}{|c|c|c|c|}
\hline $\begin{array}{c}\text { Компоненты } \\
\text { архитектурно- } \\
\text { пространственной } \\
\text { среды }\end{array}$ & $\begin{array}{c}\text { Показатели } \\
\text { из нормативных } \\
\text { документов }\end{array}$ & Описание & $\begin{array}{c}\text { Показатель } \\
\text { соответствия } \\
\text { компонента АПС } \\
\text { существующим } \\
\text { нормативам }\end{array}$ \\
\hline \multicolumn{4}{|c|}{ Дорожки } \\
\hline $\begin{array}{ll}\text { Возле } & \text { главного } \\
\text { входа } & \end{array}$ & \multirow{6}{*}{$\begin{array}{l}\text { Не менее } 1,5 \text { м в ши- } \\
\text { рину при односторон- } \\
\text { нем движении лиц на } \\
\text { креслах-колясках; по- } \\
\text { крытие твердое, проч- } \\
\text { ное, не скользящее, } \\
\text { толщина швов между } \\
\text { плитками не более } \\
10 \text { мм, контрастируют } \\
\text { с цветом и фактурой } \\
\text { прилегающих поверх- } \\
\text { ностей }\end{array}$} & $\begin{array}{l}\text { Из бетонных плит, которые расположены } \\
\text { попарно в ряду, плоскость всех плит не вы- } \\
\text { ровнена, большие зазоры между плитами, } \\
\text { ширина } 1,4 \text { м }\end{array}$ & $\begin{array}{l}\text { Ширина - нет } \\
\text { Тип покрытия - да } \\
\text { Выровненность - нет }\end{array}$ \\
\hline Подход к стадиону & & $\begin{array}{l}\text { Песчаная дорожка шириной } 0,7 \text { м с неболь- } \\
\text { шой степенью каменистости, по обеим сто- } \\
\text { ронам находится бордюр }\end{array}$ & \begin{tabular}{|l|} 
Ширина - нет \\
Тип покрытия - да \\
Выровненность - нет \\
\end{tabular} \\
\hline $\begin{array}{l}\text { Дорожка с заднего } \\
\text { двора до школы }\end{array}$ & & $\begin{array}{l}\text { Асфальтированная, покрытие старое, неров- } \\
\text { ное, с трещинами и выбоинами, ширина ко- } \\
\text { леблется на протяжении всей дорожки, } \\
\text { сужается к отдалению от школы, минималь- } \\
\text { ные размер } 80 \text { см, максимально } 1,5 \text { м }\end{array}$ & $\begin{array}{l}\text { Ширина - нет } \\
\text { Тип покрытия - да } \\
\text { Выровненность - нет }\end{array}$ \\
\hline $\begin{array}{l}\text { Вдоль яблоневого } \\
\text { сада }\end{array}$ & & $\begin{array}{l}\text { Асфальтированная, покрытие старое, неров- } \\
\text { ное, с выбоинами, ширина } 3 \text { м }\end{array}$ & \begin{tabular}{|l|} 
Ширина - нет \\
Тип покрытия - да \\
Выровненность - нет \\
\end{tabular} \\
\hline Беговая дорожка & & $\begin{array}{l}\text { Асфальтированная и на небольшом участке } \\
\text { пути полупесчаная, покрытие старое, неров- } \\
\text { ное, с трещинами и выбоинами, ширина ко- } \\
\text { леблется на протяжении всей дорожки }\end{array}$ & $\begin{array}{l}\text { Ширина - нет } \\
\text { Тип покрытия - да } \\
\text { Выровненность - нет }\end{array}$ \\
\hline Дорога & & $\begin{array}{l}\text { Предназначена для комфортабельного } \\
\text { подъезда непосредственно ко входу школы, } \\
\text { имеет ширину } 3,5 \text { м, покрытие - асфальт }\end{array}$ & \begin{tabular}{|l|} 
Ширина - нет \\
Тип покрытия - да \\
Выровненность - нет \\
\end{tabular} \\
\hline \multicolumn{4}{|c|}{ Площадки } \\
\hline \begin{tabular}{lll|} 
Возле & входа & в \\
школу & &
\end{tabular} & \multirow{4}{*}{$\begin{array}{l}\text { Вне границ пеше- } \\
\text { ходного пути, углы } \\
\text { должны быть скруг- } \\
\text { лены }\end{array}$} & $\begin{array}{l}\text { Имеет достаточно крупные размеры, покры- } \\
\text { тие аналогично дороге, площадка выровнена }\end{array}$ & \begin{tabular}{|l|} 
Ширина - нет \\
Тип покрытия - да \\
Выровненность - нет
\end{tabular} \\
\hline Внутренний двор & & $\begin{array}{l}\text { Имеет достаточно крупные размеры, покры- } \\
\text { тие аналогично дороге, площадка выровнена }\end{array}$ & \begin{tabular}{|l|} 
Ширина - нет \\
Тип покрытия - да \\
Выровненность - нет \\
\end{tabular} \\
\hline $\begin{array}{ll}\text { Спортивная пло- } \\
\text { щадка }\end{array}$ & & $\begin{array}{l}\text { Имеет достаточно крупные размеры, покры- } \\
\text { тие - асфальт с высокой степенью каменисто- } \\
\text { сти, площадка выровнена }\end{array}$ & \begin{tabular}{|l|} 
Ширина - нет \\
Тип покрытия - да \\
Выровненность - нет \\
\end{tabular} \\
\hline $\begin{array}{l}\text { Площадка за шко- } \\
\text { лой }\end{array}$ & & $\begin{array}{l}\text { Имеет достаточно крупные размеры, покры- } \\
\text { тие аналогично дороге, площадка выровнена }\end{array}$ & \begin{tabular}{|l|} 
Ширина - нет \\
Тип покрытия - да \\
Выровненность - нет \\
\end{tabular} \\
\hline \multicolumn{4}{|c|}{ Входы и выходы } \\
\hline $\begin{array}{l}\text { Главный вход на } \\
\text { территорию }\end{array}$ & \multirow[t]{2}{*}{$\begin{array}{l}\text { Ширина пандуса не } \\
\text { менее } 1 \text { м, уклон } \\
\text { марша при его длине } \\
\text { до } 10 \text { м не более } 10 \% \text {, } \\
\text { высота подъема марша } \\
\text { не более } 0,8 \text { м, вход }\end{array}$} & $\begin{array}{l}\text { Осуществляется с главной улицы, есть ме- } \\
\text { сто, не препятствует движению, ждать, пока } \\
\text { откроют ворота для заезда на территорию, } \\
\text { рядом калитка, через которую осуществля- } \\
\text { ется вход пешеходов }\end{array}$ & Да \\
\hline $\begin{array}{l}\text { Дополнительный } \\
\text { вход на террито- } \\
\text { рию }\end{array}$ & & $\begin{array}{l}\text { Осуществляется с дороги, не являющейся } \\
\text { главной, ворота старые, хорошо работаю- } \\
\text { щие, для транспорта }\end{array}$ & Да \\
\hline $\begin{array}{l}\text { Вход во внутрен- } \\
\text { ний двор (арка) }\end{array}$ & \multirow{3}{*}{$\begin{array}{l}\text { Количество ступеней } \\
\text { в марше от } 3 \text { до 12, по- } \\
\text { сле каждого марша } \\
\text { пандус, длина кото- } \\
\text { рого не менее } 1,5 \text { м, } \\
\text { форма ступеней оди- } \\
\text { накова по всей длине } \\
\text { марша, высота ступе- } \\
\text { ней не более } 12 \text { см и } \\
\text { ширина не менее } 40 \text { см }\end{array}$} & $\begin{array}{l}\text { Выполнен в виде арки, высота } 3 \text { м и ширина } \\
3,7 \text { м, предназначен для комфортного про- } \\
\text { езда транспорта }\end{array}$ & Да \\
\hline $\begin{array}{l}\text { Вход во внутрен- } \\
\text { ний двор (со } \\
\text { школы) }\end{array}$ & & $\begin{array}{l}\text { Представляет собой } 2 \text { двери, находящиеся на } \\
\text { расстоянии } 3 \text { м друг от друга, двери стеклян- } \\
\text { ные, они выходят на площадку шириной } 1 \text { м с } \\
2 \text { лестницами напротив дверей, площадка обо- } \\
\text { рудована поручнями и ограждениями, ширина } \\
\text { лестниц } 0,85 \text { м, ступени разные по высоте, по- } \\
\text { чти одинаковые по ширине, без пандусов }\end{array}$ & Нет \\
\hline $\begin{array}{l}\text { Главный вход в } \\
\text { школу }\end{array}$ & & $\begin{array}{l}\text { Лестница широкая, высота ступеней и их ши- } \\
\text { рина одинаковы, есть пандус с поручнями }\end{array}$ & Да \\
\hline
\end{tabular}


К рекомендациям по ландшафтной адаптации архитектурно-пространственной среды учреждений общего среднего образования относится создание ландшафтной предметно-развивающей среды, которая основывается на следующих принципах:

- полифункциональность: предметно-развивающая среда должна открывать перед детьми множество возможностей и должна быть многофункциональной;

- трансформированность: представляет возможность вносить изменения, позволяющие по ситуации, вынести на первый план ту или иную функцию пространства;

- вариативность: предметно-развивающая среда предполагает периодичную сменяемость материала;

- насыщенность: среда соответствует содержанию образовательной программы;
- доступность: среда обеспечивает свободный доступ детей к играм, материалам, учебным пособиям;

- безопасность: среда предполагает соответствие по обеспечению надежности и безопасности.

Предполагаемые ландшафтные зоны архитектурно-пространственной среды: учебная зона, игровая зона, зона творчества, зона краеведения, хозяйственный двор, зона безопасности, зона безопасности дорожного движения, зона правового всеобуча, уголок здоровья, информационная зона и др. Адаптированы зоны способствуют детям с ограниченными возможностями понять, что они так же полноценны, как и все люди. Проводить мероприятия по адаптации необходимо начинать с их психологической зоны комфорта, помочь им преодолеть каждодневную борьбу с несамостоятельностью, потому что большая часть того, что их окружает, не предназначено для полноценного потребления.

\section{Список литературы}

1. БЕЛТА - новости Беларуси / В Беларуси более $70 \%$ детей с особенностями развития обучаются в интегрированных классах. 3 дек. 2020. Режим доступа: https://www.belta.by/society/view/v-belarusi-bolee-70-detejs-osobennostjami-razvitija-obuchajutsja-vintegrirovannyh-klassah-418522-2020/ (дата обращения: 17.01.2021).

2. Кодекс Республики Беларусь об образовании от 13.01.2011 г. № 243-3. Минск, 2010. 400 с.

3. Национальный план действий по реализации в Республике Беларусь положений Конвенции о правах инвалидов на 2017-2025 годы от 13.06.2017. № 451. Минск, 2017. 11 с.

4. Студопедия / Понятие об архитектурной среде. Режим доступа: https://studopedia.info/1-17630.html (дата обращения: 17.01.2021).

5. Хачатрянц К. К., Мазаник А. В., Иваницкая Е. А. Среда обитания для физически ослабленных лиц. Основные положения. Техническое нормирование и стандартизация: ГОСТ/ Репозиторий БНТУ. Минск, 2017. С. 24-25. Режим доступа: https://rep.bntu.by/bitstream/handle/data/4811/c. (дата обращения: 17.01.2021).

6. Хачатрянц К. К. Развитие нормативной базы проектирования среды обитания, адаптированной к возможностям физически ослабленных лиц. Теория и история архитектуры/ Репозиторий БНТУ. Минск, 2011. C. 60-66. Режим доступа: https://core.ac.uk/reader/323161273 (дата обращения: 17.01.2021).

7. О социальной защите инвалидов в Республике Беларусь: Закон Респ. Беларусь от 11.11 .1991 (ред. от 16.11.2010). № 1224-XII, гл. 6. Минск, 2010. 11 с. Режим доступа: http://mintrud.gov.by/ system/extensions/spaw/uploads/files/ZAKON-RB-O-sotsialnoj-zaschite-invalidov-v-Respublike-Belarus.pdf (дата обращения: 17.01.2021).

8. О предупреждении инвалидности и реабилитации инвалидов: Закон Респ. Беларусь от 23.07.2008 (ред. от 12.12.2013). № 422-3. Минск, 2013. 15 с. Режим доступа: http://mintrud.gov.by/ system/extensions/spaw/uploads/files/ZAKON-RB-O-preduprezhdenii-invalidnosti-i-reabilitatsii-invalidov.pdf (дата обращения: 17.01.2021).

9. О государственной программе по созданию безбарьерной среды жизнедеятельности физически ослабленных лиц на 2011-2015 годы: постановление Совета министров Респ. Беларусь от 1 нояб. 2010 г. (ред. от 04.09.2014). № 1602. Минск, 2014. 44 с. Режим доступа: http://www.mintrud.gov.by/system/ extensions/spaw/uploads/files/Programma-po-sozdaniju-bezbarjernoj-sredy-1.pdf (дата обращения: 17.01.2021).

10. Об утверждении и введении в действие технических нормативных правовых актов в строительстве: приказ М-ва архитектуры Респ. Беларусь от 17.12.2007 (ред. от 02.05.2014, с изм. от 26.08.2014). № 409. Минск, 2014.

11. Среда обитания для физически ослабленных лиц: СТБ 2030-2010. Введ. 01.08.2010 (изм. 01.01.2014). Минск, 2014.

12. Административные и бытовые здания: СНБ 3.02.03-03 (взамен СНиП 2.09.04-87): утв. приказом М-ва архитектуры и строительства Респ. Беларусь от 28 июля 2003 г. № 142. Минск, 2003.

13. Жилые здания: СНБ 3.02.04-03: утв. приказом М-ва архитектуры и строительства Респ. Беларусь от 26.08.2003 г. № 165. Минск, 2003.

14. Общественные здания и сооружения. Строительные нормы проектирования: ТКП 45-3.02-290-2013: утв. приказом М-ва архитектуры и строительства Респ. Беларусь от 11.10.2013 г. № 389. Минск, 2013.

15. Здания и помещения розничных торговых объектов: ТКП 45-3.02-240-2010: утв. приказом М-ва архитектуры и строительства Респ. Беларусь от 22.04.2011 г. № 133. Минск, 2014. 


\section{References}

1. BELTA - novosti Belarusi [Belarus news] / In Belarus, more than $70 \%$ of children with special needs are taught in integrated classes. December 3, 2020. Available at: https:/www.belta.by/society/view/v-belarusi-bolee70-detej-s-osobennostjami-razvitija-obuchajutsja-v-integrirovannyh-klassah-418522-2020/ (accessed 17.01.2021).

2. Kodeks Respubliki Belarus' ob obrazovanii [The Code of the Republic of Belarus on Education]. Minsk, 2010. 400 p.

3. Natsional'nyy plan deystviy po realizatsii v Respublike Belarus' polozheniy Konventsii o pravakh invalidov na 2017-2025 gody [National action plan for the implementation in the Republic of Belarus of the provisions of the Convention on tht Rights of Persons with Disabilities for 2017-2025]. Minsk, 2017.11 p.

4. Studopediya. Ponyatiye ob arkhitekturnoy srede [Studopedia. Understanding the architecture environment]. Available at: https://studopedia.info/1-17630.html (accessed 17.01.2021).

5. Khachatryants K. K., Mazanik A. V., Ivanitskaya E. A. Sreda obitaniya dlya fizicheski oslablennykh lits. Osnovnyye polozheniya. Tekhnicheskoye normirovaniye i standartizatsiya [State Standard of the Republic of Belarus "Habitat for physically impaired persons. Basic provisions"]. Minsk, 2017, pp. 24-25. Available at: https://rep.bntu.by/bitstream/handle/data/4811/c (accessed 17.01.2021).

6. Khachatryants K. K. Razvitiye normativnoy bazy proyektirovaniya sredy obitaniya, adaptirovannoy $k$ vozmozhnostyam fizicheski oslablennykh lits. Teoriya i istoriya arkhitektury [Development of a regulatory framework for designing a living environment adapted to the capabilities of physically disabled persons. Theory and history of architecture]. Minsk, 2011, pp. 60 - 66. Available at: https://core.ac.uk/reader/323161273 (accessed 17.01.2021).

7. O sotsial'noy zashchite invalidov v Respublike Belarus'?: Zakon Resp. Belarus', 11.11.1991, №. 1224$X I I$, ch. 6 [About social protection of disabled people in the Republic of Belarus: the Law of the Republic of Belarus of 11.11.1991 (ed. of 16.11.2010), no. 1224-XII (ch. 6) ]. Minsk, 2010. 11 p. Available at: http://mintrud.gov.by/system/extensions/spaw/uploads/files/ZAKON-RB-O-sotsialnoj-zaschite-invalidovv-Respublike-Belarus.pdf (accessed 17.01.2021).

8. O preduprezhdenii invalidnosti i reabilitatsii invalidov: Zakon Resp. Belarus', 23.07.2008, № 422-3 [On the prevention of disability and rehabilitation of disabled people: Law of the Republic of Belarus of 23.07.2008 (ed. of 12.12.2013), no. 422-Z]. Minsk, 2013. 15 p. Available at: http://mintrud.gov.by/system/extensions/spaw/uploads/files/ZAKON-RB-O-preduprezhdenii-invalidnosti-i-reabilitatsii-invalidov.pdf (accessed 17.01.2021).

9. O gosudarstvennoy programme po sozdaniyu bezbar'yernoy sredy zhiznedeyatel'nosti fizicheski oslablennykh lits na 2011-2015 gody: postanovleniye Soveta ministrov Resp. Belarus', 1 noyab. 2010 g., № 1602 [On the state program for creating a barrier-free living environment for physically disabled persons for 2011-2015: Resolution of the Council of Ministers of the Republic of Belarus of November 1, 2010 (ed. from 04.09.2014), no. 1602]. Minsk, 2014. 44 p. Available at: http://www.mintrud.gov.by/system/extensions/spaw/uploads/files/Programma-po-sozdaniju-bezbarjernoj-sredy-1.pdf (accessed 17.01.2021).

10. Ob utverzhdenii $i$ vvedenii v deystviye tekhnicheskikh normativnykh pravovykh aktov $v$ stroitel'stve : Prikaz Ministerstva stroitel 'stva i arkhitektury Resp. Belarus', 17.12.2007 g., № 409 [On the approval and introduction of technical regulatory legal acts in construction: order of the Ministry of Architecture of the Republic of Belarus. Belarus from 17.12.2007 (ed. from 02.05.2014, with amendments. dated 26.08.2014), no. 409]. Minsk, 2014.

11. CTB 2030-2010. Habitat for physically disabled persons. Minsk, 2014 (In Russian).

12. CNB 3.02.03-03. Administrative and household buildings. Minsk, 2003 (In Russian).

13. CNB 3.02.04-03. Residential buildings. Minsk, 2003 (In Russian).

14. TCP 45-3. 02-290-2013. Public buildings and structures. Building design standards. Minsk, 2013 (In Russian).

15. TCP 45-3. 02-240-2010. Buildings and premises of retail trade objects. Minsk, 2014 (In Russian).

\section{Информация об авторах}

Евсеева Ольга Петровна - кандидат педагогических наук, доцент кафедры ландшафтного проектирования и садово-паркового строительства. Белорусский государственный технологический университет (220006, г. Минск, ул. Свердлова 13a, Республика Беларусь). E-mail: Ol-evseeva@mail.ru

Шумская Полина Валентиновна - студент. Белорусский государственный технологический университет (220006, г. Минск, ул. Свердлова 13a, Республика Беларусь). E-mail: pollytoter@yandex.by

\section{Information about the authors}

Evseeva Olga Petrovna - PhD Pedagogical, Associate Professor, the Department of Landscape Design and Landscape Construction. Belarusian State Technological University (13a, Sverdlova str., Minsk, 220006, Republic of Belarus). E-mail: Ol-evseeva@mail.ru

Shumskaya Polina Valentinovna - student. Belarusian State Technological University (13a, Sverdlova str., Minsk, 220006, Republic of Belarus). E-mail: pollytoter@yandex.by 